\author{
Algirdas Revaitis \\ The General Jonas Žemaitis Military Academy of Lithuania
}

\title{
Contemporary Warfare Discourse in Russia's Military Thought
}

\begin{abstract}
This article analyses the Russian concept of contemporary warfare after the 2008 Russia-Georgia war and the changes that have occurred in the wake of the 2014 military conflict in Eastern Ukraine. This concept is shaped through a dissection of public texts and speeches by Russian military officers, experts and analysts. The article attempts to measure the impact of Russia's military practice in Eastern Ukraine in its stance on contemporary warfare and see what new types of warfare (terminologically speaking) are appearing in Russia's military vocabulary. A vision of the future of types of Russian war is presented, complete with arguments regarding the most plausible case of future local war with respect to Russia. The article furthermore provides a detailed analysis of the interpretations of asymmetrical, network-centric, hybrid warfare, colour revolutions, controlled chaos, and information and electromagnetic warfare in Russia's military thought, which is understood as forms of realisation of contemporary warfare. A quest for the origin of these warfare ideas shows that Russia tends to emulate the military experience of western powers, the US in particular, instead of doing the opposite and acting adaptively and conceptualising its most recent military experience as a vision of modern warfare.
\end{abstract}

\section{Introduction}

The object of this study is the expression of texts by Russian military officers and experts as an indication of the concept of contemporary warfare in Russian military thought. The public texts that are analysed within the framework of this study are split into two groups: (1) the way Russia has understood and interpreted contemporary warfare since the 2008 Russia-Georgia war; and (2) the way this understanding changed after the outbreak of the military conflict in Ukraine in 2014.

In 2014, Russia's blitzed occupation of the Crimea ${ }^{1}$ and the ongoing covert military support to the separatists involved in the conflict in Eastern

\footnotetext{
*Algirdas Revaitis is a PhD candidate at the Department of Political Science of the General Jonas Žemaitis Military Academy of Lithuania. Address for correspondence: Šilo 5A, LT-10322 Vilnius, tel.+370 5 2126923, e-mail: revaitis.algirdas@gmail.com.

${ }^{1}$ Christopher M., Putin discusses secret meeting when he gave order to annex Crimea, 09/03/2015, https://mashable.com/2015/03/09/putin-describes-meeting-annex-crimea/\#9J5Kk5D9Iiqb, 23/03/2018.
}

DOI: 10.2478/lasr-2018-0010

(C) Algirdas Revaitis, 2018

(C) Military Academy of Lithuania, 2018 
Ukraine ${ }^{2}$ have proved that even today armed forces can be used against another state in a surprise and unorthodox way to further the geopolitical goals of the country. Even though no attempt by Russia to rely on its military power outside its own national borders goes unnoticed by western warfare and security experts, this case was unique in a way that Russian armed forces had demonstrated a highly unusual, efficient and refined form of contemporary warfare. The innovative format of Russia's aggression in Ukraine made NATO rethink the context of the transformed threats and look for answers to questions regarding to what extent and how Russia thinks about modern war, and how it prepares to wage it.

These processes highlight the active goals of researchers to reflect the characteristics of Russia's aggression in Ukraine and understand modern Russian military thought and, most importantly, discover the ideological roots of this type of warfare. There are four groups of warfare experts that can be identified in this discussion, which first started in February 2014 and is still ongoing, defined by their choice to analyse the conceptual and physical element of Russia's military power, their inclination to rely on Russian or rather more western sources, and their decision (not) to apply western conceptual forms of warfare in theorising about Russia’s military practices in Ukraine. For the purposes of this study, the most important works are those that attempt to provide conceptual directions of Russia's warfare in Ukraine and crystallise the cornerstone military terms and types of warfare ${ }^{3}$ that Russia uses when it thinks about the specifics of contemporary military conflict.

The first group of military experts (Keir Giles ${ }^{4}$, Alexander Golts 5 , Roger

\footnotetext{
${ }^{2}$ Czuperski M., Herbst J., Higgins E., Polyakova A., Wilson D., Hiding in Plain Sight: Putin’s War in Ukraine, The Atlantic Council of the United States, 2015.

${ }^{3}$ The warfare type (form) and military conception notions are considered as synonymous in the article. It describes the methods or scheme of actions used to utilise specific (material and non-material) military capabilities, is aiming to fulfil an essential mission or to implement specified tasks.

${ }^{4}$ Giles K., 'A New Phase in Russian Military Transformation', The Journal of Slavic Military Studies 1 (27), 2014, p. 147-162, http://www.tandfonline.com.ezproxy.lka.lt/doi/full/10.1080/13518046.2014.874850, $11 / 10 / 2017$.

${ }^{5}$ Golts A., 'Reform: The End of the First Phase - Will There Be a Second?', The Journal of Slavic Military Studies 1 (27), 2014, p. 131-146, http://www.tandfonline.com.ezproxy.lka.lt/doi/full/10.1080/13518046.20 $14.874847,11 / 10 / 2017$.
} 
N. McDermott ${ }^{6}$, James A. Marshall ${ }^{7}$, Daivis Petraitis ${ }^{8}$, Bettina Renz ${ }^{9}$ ) focus on Russia's military reform that kicked off after the Russia-Georgia military conflict in 2008; however, the work of these researchers is basically devoid of any attempts to connect Russia's military acts in Ukraine to the ongoing military reform. We can only single out the work by Charles K. Bartles and McDermott, in which the authors are trying to figure out how the new form of organising Russia's armed forces affected the execution of the Crimea operation ${ }^{10}$. This study supports the results of previous studies on Russian military reform and at the same time contains new insights into the practical aspects of the employment of Russia's forces after the reform. It has to be stressed that the works that fall into this group are void of any attempts to dissect the qualities of military thought or warfare that would reflect Russia's conceptual approach towards forms of contemporary warfare.

The work of the second group of experts (Diego A. R. Palmer ${ }^{11}$, Henrik Praks $^{12}$, Andreas Jacobs and Guillaume Lasconjarias ${ }^{13}$, Vira Ratsiborynska ${ }^{14}$, Jeffrey Larsen ${ }^{15}$, Uwe Hartmann ${ }^{16}$, Andrew Radin ${ }^{17}$, Max Boot ${ }^{18}$, Rod Thorn-

\footnotetext{
${ }^{6}$ McDermott N. R., 'The Brain of the Russian Army: Futuristic Visions Tethered by the Past', The Journal of Slavic Military Studies 1 (27), 2014, p. 4-35, http://www.tandfonline.com.ezproxy.lka.lt/doi/full/10.1080/13 518046.2014.874840, 11/10/2017.

${ }^{7}$ Marshall J. A., 'Russia's Struggle for Military Reform: A Breakdown in Conversion capabilities', The Journal of Slavic Military Studies 2 (27), 2014, p. 189-209, http://www.tandfonline.com.ezproxy.lka.lt/doi/full/1 $0.1080 / 13518046.2013 .844488,11 / 10 / 2017$.

${ }^{8}$ Petraitis D., 'Is Russian Military Back on Its Feet', Journal on Baltic Security 1 (1), 2015, p. 85-95.

${ }^{9}$ Renz B., 'Russian Military Capabilities after 20 Years of Reform', Survival 3 (56), 2014, p. 61-84, http:// dx.doi.org/10.1080/00396338.2014.920145, 12/10/2017.

${ }^{10}$ Bartles K. C., McDermott N. R., 'Russia's Military Operation in Crimea', Problems of Post-Communism 6 (61), p. 46-63, http://dx.doi.org/10.2753/PPC1075-8216610604.2014.11083050, 11/10/2017.

${ }^{11}$ Palmer D. A. R., 'Back to the Future? Russia's Hybrid Warfare, Revolutions in Military Affairs, and Cold War Comparisons', NATO Defense College Research paper 120, 2015.

${ }^{12}$ Praks H., 'Hybrid or Not: Deterring and Defeating Russia's Ways or Warfare in the Baltic States - the Case of Estonia, NATO Defense College Research paper 124, 2015.

${ }^{13}$ Jacobs A., Lasconjarias G., 'NATO's Hybrid Flanks. Handling Unconventional Warfare in the South and the East', NATO Defense College Research paper 112, 2015.

${ }^{14}$ Ratsiborynska V., 'When Hybrid Warfare Supports Ideology: Russia Today', NATO Defense College Research paper 133, 2016.

${ }^{15}$ Larsen J., Lasconjarias G., NATO's Response to Hybrid Threats, Rome: NATO Defense College, 2015, p. $1-14$.

${ }^{16}$ Hartmann U., 'The Evolution of the Hybrid Threat, and Resilience as a Countermeasure', NATO Defense College Research paper 139, 2017.

${ }^{17}$ Radin A., 'Hybrid Warfare in the Baltics: Threats and Potential Response', RAND Corporation, 2017.

${ }^{18}$ Boot M., 'Countering Hybrid Warfare', Armed Conflict Survey 1 (1), 2015, p. 11-20, https://doi.org/10.10 80/23740973.2015.1041721, 12/10/2017
} 
ton $^{19}$, Matthew Kroenig ${ }^{20}$, Olevs Nikers ${ }^{21}$, Alexander Lanoszka ${ }^{22}$, Amos C. Fox and Andrew J. Rossow ${ }^{23}$ ) is dominated by the military concept of hybrid warfare, which is considered to be most appropriate for the purposes of explaining Russia's military actions in Ukraine. Yet these works ground the theoretical concept of hybrid warfare on western military texts written before 2014 by the following experts on warfare: William J. Nemeth $(2002)^{24}$, Frank G. Hoffmann $(2007)^{25}$, John J. McCuen $(2008)^{26}$, Russell Glenn (2009) ${ }^{27}$, Timothy B. McCulloh and Richard Johnson (2013) ${ }^{28}$. Notably, this group of researchers do not analyse Russian sources that back up the suitability of hybrid warfare for conceptualising Russia's practical actions but rather accentuate the genesis of hybrid warfare ideas in the West, ideas that Russia successfully tapped and brought to life in Ukraine.

The third group includes analysts who try to understand Russia's warfare in Ukraine by studying western military concepts and looking deeper into Russia’s military discourse (Russian military-analytical texts, non-analytical articles, speeches, reports and so on). In this group, we find works by Peter Mattsson $^{29}$, Miroslaw Banasik ${ }^{30}$, Hall Gardner ${ }^{31}$, Dave Johnson ${ }^{32}$, Jacob W.

\footnotetext{
${ }^{19}$ Thornton R., 'The Changing Nature of Modern Warfare', The RUSI Journal 4 (160), 2015, p. 40-48, http:// dx.doi.org/10.1080/03071847.2015.1079047, 12/10/2017.

${ }^{20}$ Kroenig M., 'Facing Reality: Getting NATO Ready for a New Cold War', Survival 1 (57), 2015, p. 49-70, http://dx.doi.org/10.1080/00396338.2015.1008295, 12/10/2017.

${ }^{21}$ Nikers O., 'Ukraine-Style Hybrid War Unlikely in Latgale, The Jamestown Foundation, 11 March 2016, https://jamestown.org/program/ukraine-style-hybrid-war-unlikely-in-latgale/, 13/10/2017.

${ }^{z z}$ Lanoszcka A., 'Russian Hybrid Warfare and Extended Deterrence in Eastern Europe', International Affairs 1 (92), p. 175-195.

${ }^{23}$ Fox A. C., Rossow A. J., 'Making Sense of Russian Hybrid Warfare: A Brief Assessment of the RussoUkrainian War', The Institute of Land Warfare: The Land Warfare papers 112, 2017.

${ }^{24}$ Nemeth J. W., 'Future War and Chechnya: A Case for Hybrid Warfare', Naval Postgraduate School, 2002, https://calhoun.nps.edu/bitstream/handle/10945/5865/02Jun_Nemeth.pdf?sequence=1, 16/10/2017.

${ }^{25}$ Hoffmann F. G., 'Conflict in the 21st century: the rise of hybrid wars', Potomac Institute for Policy Studies, 2007, http://www.potomacinstitute.org/images/stories/publications/potomac_hybridwar_0108.pdf, $16 / 10 / 2017$.

${ }^{26}$ John J. McCuen, 'Hybrid Wars', Military Review, 2008, p. 107-113, http://www.armyupress.army.mil/ Portals/7/military-review/Archives/English/MilitaryReview_20080430_art017.pdf, 17/10/2017.

${ }^{27}$ Glenn R. W., 'Thoughts on Hybrid Conflict', Small Wars Journal, 2009, http://smallwarsjournal.com/jrnl/ art/thoughts-on-hybrid-conflict, 17/10/2017.

${ }^{28}$ Johnson R., McCulloh B. T., Hybrid Warfare, Florida: Joint Special Operations University Report 13-4, 2013.

${ }^{29}$ Mattsson P., 'Russian Military Thinking - A New Generation of Warfare', Journal on Baltic Security 1 (1), 2015, p. 61-70.

${ }^{30}$ Banasik M., 'Russia‘s Hybrid War in Theory and Practice', Journal on Baltic Security 1 (2), 2016, p. $157-182$.

${ }^{31}$ Gardner H., 'Hybrid Warfare: Iranian and Russian Versions of "Little Green Men" and Contemporary Conflict', NATO Defense College Research paper 123, 2015.

${ }^{32}$ Johnson D., 'Russia's Approach to Conflict - Implications for NATO's Deterrence and Defence', NATO Defense College Research paper 111, 2015.
} 
Kipp $^{33}$, Thornton ${ }^{34}$, Ofer Fridman ${ }^{35}$, Lawrence Freedman ${ }^{36}$, Can Kasapoglu ${ }^{37}$, Andras Racz ${ }^{38}$, Bret Perry ${ }^{39}$, Samuel Charap ${ }^{40}$, Merle Maigre ${ }^{41}$, Oscar Jonsson and Robert Seely ${ }^{42}$. These works in their entirety reveal an ambiguous stance on the form of Russia's warfare in Ukraine. In order to define Russia's contemporary warfare, the experts use different terms and concepts, the most popular being hybrid war, new-generation warfare, reflective control, full-spectrum conflict, non-linear warfare, limited war and asymmetric (unconventional) warfare. Quite importantly, these researchers try to understand Russian military thought by analysing Russian texts in reliance on western conceptual ideas. Still, these works do not leave the western concept of hybrid warfare on the sidelines and use it in a bid to conceptualise Russia's warfare in Ukraine.

Group number four consists of the most active researchers of warfare

\footnotetext{
${ }^{33}$ Kipp W. J., "'Smart" Defense From New Threats: Future War From a Russian Perspective: Back to the Future After the War on Terror', The Journal of Slavic Military Studies 1 (27), 2014, p. 32-64, https://doi.org /10.1080/13518046.2014.875744, 11/10/2017.

${ }^{34}$ Thornton R., 'The Russian Military's New “Main Emphasis”, The RUSI Journal 4 (162), 2017, p. 18-28, http://dx.doi.org/10.1080/03071847.2017.1381401, 12/10/2017.

${ }^{35}$ Fridman O., 'Hybrid Warfare or Gibridnaya Voyna', The RUSI Journal 1 (162), 2017, p. 42-49, http:// dx.doi.org/10.1080/03071847.2016.1253370, 12/10/2017.

${ }^{36}$ Freedman L., 'Ukraine and the Art of Limited War', Survival 6 (56), 2014, p. 7-38, http://dx.doi.org/10.10 80/00396338.2014.985432, 12/10/2017.

${ }^{37}$ Kasapoglu C., 'Russia’s Renewed Military Thinking: Non-linear Warfare and Reflective Control', NATO Defense College Research paper 121, 2015.

${ }^{38}$ Rasz A., Russia's Hybrid War in Ukraine, Helsinki: The Finish Institute of International Affairs, Report 43, p. 104.

${ }^{39}$ Perry B., 'Non-Linear Warfare in Ukraine: The Critical Role of Information Operations and Special Operations', Small Wars Journal, 2015, http://smallwarsjournal.com/jrnl/art/non-linear-warfare-in-ukrainethe-critical-role-of-information-operations-and-special-opera, 17/10/2017.

${ }^{40}$ Charap S., 'The Ghost of Hybrid War', Survival 6 (57), 2015, p. 51-58, http://dx.doi.org/10.1080/0039633 8.2015.1116147, 12/10/2017.

${ }^{41}$ Maigre M., 'Nothing New in Hybrid Warfare: The Estonian Experience and Recommendations for NATO', The Germany Marshall Fund of The United States, Foreign Policy Program, Policy Brief Paper, 2015, http://www.gmfus.org/publications/nothing-new-hybrid-warfare-estonian-experience-and-recommendations-nato, 18/10/2017.

${ }^{42}$ Jonsson O., Seely R., 'Russian Full-Spectrum Conflict: An Appraisal after Ukraine', The Journal of Slavic Military Studies 1 (28), 2015, p. 1-22, http://dx.doi.org/10.1080/13518046.2015.998118, 18/10/2017.
} 
$\left(\mathrm{McDermott}^{43}\right.$, Mark Galeotti ${ }^{44}$, Timothy Thomas ${ }^{45}$, Jan Berzinš $\left.{ }^{46}\right)$, whose analysis of the Russian military discourse is as focused as it is deep. These warfare experts concern themselves with the analysis of Russian texts (admittedly in reliance to the same works by Russia's warfare experts and military elite first and foremost ${ }^{47}$ ) and support the position that the term hybrid warfare should not be used to define Russia's actions in Ukraine. Still, the experts diverge on the military concepts that Russia uses to operationalise contemporary warfare. The authors present a unique understanding of the texts, which brings into focus the following types of warfare: new-generation warfare, new-type warfare and non-linear warfare.

As an overview of western intellectual efforts to analyse contemporary Russian military thought and its realisation in the Ukrainian conflict, one could say that the experts identify different key military concepts or types of warfare that shape Russia's contemporary understanding of waging war. They predominantly lean towards putting on western 'conceptual glasses' and using insights by western experts to analyse Russia's contemporary warfare in Ukraine. The key drawback of such studies and views is that products of the Russian thought take a backseat. Nonetheless, one significant moment is the ambition to understand Russian military thought through the original texts of its officers and warfare experts, thus trying to find answers to the questions of how

\footnotetext{
${ }^{43}$ McDermott R., 'Does Russia’s "Hybrid War" Really Exist?', The Jamestown Foundation, 3 June 2015, https://jamestown.org/program/does-russias-hybrid-war-really-exist/, 18/10/2017; McDermott R., 'Myth and Reality - A Net Assessment of Russia's "Hybrid Warfare" Strategy Since the Start of 2014', The Jamestown Foundation, 17 October 2014, https://jamestown.org/program/myth-and-reality-a-net-assessmentof-russias-hybrid-warfare-strategy-since-the-start-of-2014-part-one/, 18/10/2017.

${ }^{44}$ Galeotti M., "'Hybrid War" and "Little Green Men": How it Works, and How it Doesn't', E-International Relations, 16 April 2015, http://www.e-ir.info/2015/04/16/hybrid-war-and-little-green-men-how-it-worksand-how-it-doesnt/, 18/10/2017; Galeotti M., 'The "Gerasimov Doctrine" and Russian Non-Linear War', 6 July 2014, https://inmoscowsshadow's.wordpress.com/2014/07/06/the-gerasimov-doctrine-and-russiannon-linear-war/, 18/10/2017; Galeotti M., 'Hybrid, Ambiguous, and Non-Linear? How New is Russia's "New Way of War"?', Small Wars \& Insurgencies 2 (27), 2016, http://dx.doi.org/10.1080/09592318.2015.112 9170, 18/10/2017.

${ }^{45}$ Thomas T., Thinking Like a Russian Officer: Basic Factors and Contemporary Thinking on the Nature of War, Kansas: The Foreign Military Studies office at Fort Leavenworth, p. 40; Thomas T., 'Russia's Military Strategy and Ukraine: Indirect, Asymmetric - and Putin-led', The Journal of Slavic Military Studies 3 (28), 2015, p. 445-461, http://dx.doi.org/10.1080/13518046.2015.1061819, 18/10/2017; Thomas T., 'The Evolution of Russian Military Thought: Integrating Hybrid, New-Generation, and New-Type Thinking', The Journal of Slavic Military Studies 4 (29), 2016, p. 554-575, http://dx.doi.org/10.1080/13518046.2016.12325 $41,18 / 10 / 2017$.

${ }^{46}$ Berzinš J., 'Russia’s New Generation Warfare in Ukraine: Implications for Latvian Defense Policy', Policy Paper No.2, National Defence Academy of Latvia: Center for Security and Strategic Research, 2014, http:// www.naa.mil.lv/ /media/NAA/AZPC/Publikacijas/PP\%2002-2014.ashx, 18/10/2017.

${ }^{47}$ Experts mainly are analysing papers and articles written (in the period of 1995-2016) by the following Russian military elite and war analytics: Sergei Shoigu, Valery Gerasimov, Vladimir Slipchenko, Makhmut Gareev, Viktor Riabchuk, Vladislav Surkov, Ruslan Pukhov, Sergei Chekinov, and Sergei Bogdanov.
} 
and why new military terminology emerges and which specific types of warfare become disseminated in the Russian military vocabulary. This is why the novelty of this study is grounded on the analysis of exclusively Russian military sources that will produce a better understanding of Russia's vision of modern war and present a structured concept of contemporary warfare in Russian military thought. What is more, the study aims to draw an authentic map of the types of contemporary warfare, one that would reflect the transformation of ideas in Russian military thought. Equally important it is to find out whether Russia gives any intellectual reflection to its latest military experiences in order to refresh its military thought and increase its military power.

These arguments provide grounds to define the purpose of this article as an objective to understand how Russia's military practices in Ukraine affect the understanding of contemporary warfare in Russian military thought. For the purposes of achieving the objective of the study, the following goals are formulated:

- Analysing the predominant types of warfare in Russian military thought after the 2008 war with Georgia;

- Disclosing and analysing the shift in Russian military thought of contemporary warfare after the military conflict in Ukraine that broke out in 2014.

\section{Study Method}

For the purposes of this study, military discourses are considered to consist of the whole range of individual Russian texts (analytical articles, military texts, reference articles, speeches, reports and so on) targeting the understanding of contemporary warfare in the chosen period and space. Notably, herein lies a particular degree of limitation or inaccuracy for the study, for not all Russian military texts carrying information valuable for the study were accessible. The study covers a period between August 2008 and December 2017, however the Ukrainian conflict that started in February 2014 (as an event relevant to the military context) allows us to split the Russian military discourse into two discourses that are narrower in terms of chronology (Fig. 1). 


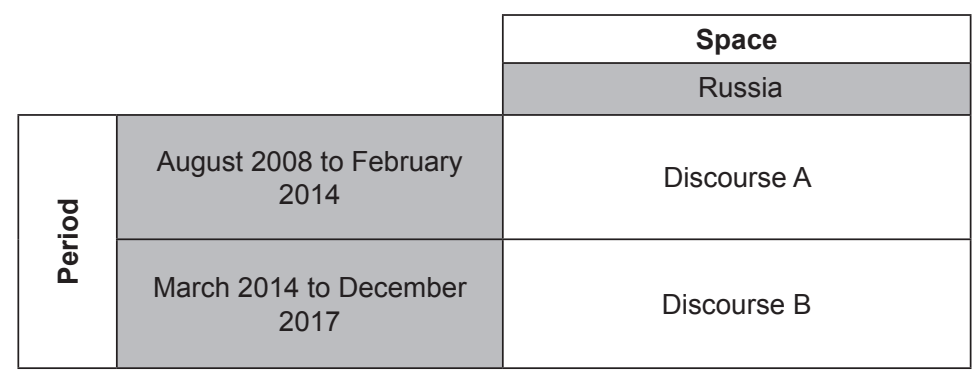

Figure 1. Military discourses by time and place

(made by the author)

Even though the method of discourse analysis to study the political reality was borrowed from language sciences, it was over a decade ago that this approach to do research was first recognised as opening new opportunities for studies in political science. Researchers stress that this method allows for the analysis of social context and its inherent features that might have possibly affected the origination of the texts ${ }^{48}$. Even though the circumstances surrounding the context are still hard to define, it is important that they be grouped on the basis of how the author of the text understands the context and its conditions. Thus, the contextual elements of interest to political science, as hints to understand the context, may be traced back through interpretation of the texts. The study follows the perspective of social constructivism, where a significant contextual event (the military conflict in Ukraine) affects a narrower discourse (the Russian understanding of contemporary warfare), thus contributing to the production of new meanings in discourse practices (in this case, texts). In the process of textual interpretation, one can recognise essential linguistic turns of discourse that reveal the causality of the production, dissemination and consumption of new types of warfare in the subject texts ${ }^{49}$.

The study analyses the Russian conception of contemporary warfare not only to identify its predominant types of warfare, their shift, methods and means of realisation, but also to trace back the sources of these ideas. The study is based on the theoretical assumption that a contextually significant military event may affect the production of new meanings in narrower discourses, with the authors of the texts reacting to significant contextual events and assigning specific meanings to the social object through their personal understanding ${ }^{50}$. Under this theoretical assumption, as a result of a contextually significant mi-

\footnotetext{
${ }^{48}$ Vinogradnaitè I., Diskurso analizè kaip politikos tyrimo metodas, Vilnius: Vilniaus universiteto leidykla, 2006, p. 5-6, 13-15.

${ }^{49}$ Phillips N., Hardy C., Discourse Analysis: Investigating Processes of Social Construction, London: Safe Publications Ltd., 2002, p. 12-13.

${ }^{50}$ Vinogradnaite, (supra note 48) p. 31-34, 37-46; Phillips, Hardy, (supra note 49) p. 8.
} 
litary event (the military conflict in Ukraine), the discourse of contemporary warfare in Russian military thought is divided into two discourses, time-wise. This allows us to evaluate the extent to which the new military practices in Ukraine contribute to the production and dissemination of new types of warfare in Russian military thought, which conveys the conceptual element of military power - the country's thinking about how it intends to form, prepare and finally use its armed forces in a future conflict.

The study consists of two parts that address two military discourses aiming to answer the underlying question of the study (Fig. 2). First, the analysis of Discourse A aims to identify cornerstone forms of warfare that dominated Russia's military vocabulary of contemporary and future conflicts after the 2008 Russia-Georgia military conflict and in doing so to understand the specifics and characteristics of their realisation and the reasons why they were produced and disseminated. With Discourse B, the analysis concerns Russian military thought on modern warfare after the events in Ukraine in order to disclose the qualitative change (production of new military terms and types of warfare in Russian military thought) compared to the results of the analysis in Discourse A. This sequence of the study is posed to allow us to better understand the ongoing changes in Russian military thought and to reveal whether Russia tends to lean towards innovative and adaptive behaviour (learning from its own experiences) or rather a tactic of emulating, absorbing and replicating military experiences, decisions and visions from other states ${ }^{51}$. The article closes with a summary of the study's results and conclusions.

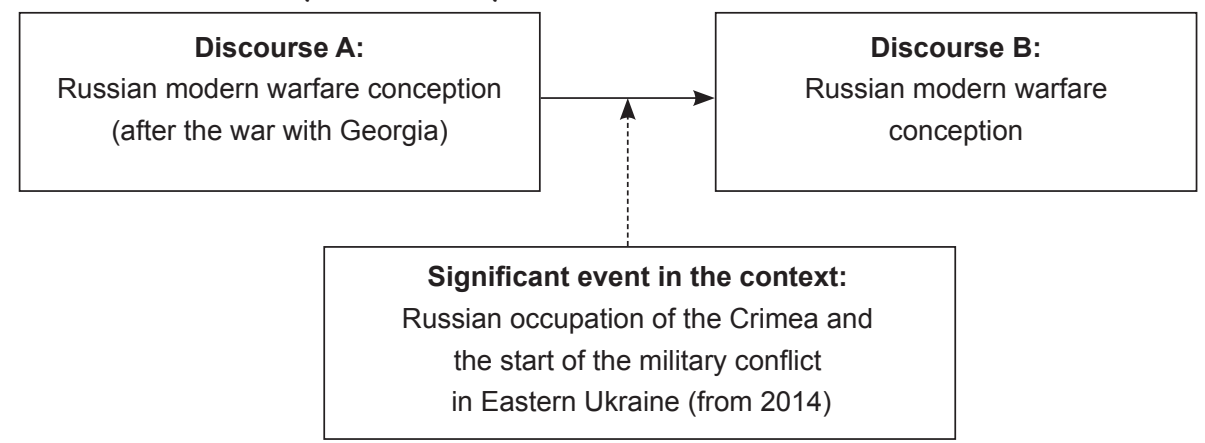

Figure 2. The logic of the study and correlation between the discourses

(made by the author)

\footnotetext{
${ }^{51}$ Scientists claim that changes in warfare can take place in three ways: (a) by innovation, (b) by adaptation or (c) by emulation. The first way is biased towards the development of new military technologies and military structures, the second way towards a renewal of military strategies, means or fighting methods during an ongoing war or conflict, and the third way focuses on the takeover processes of other states warfare forms. In: Šlekys D., Mąslaus Vyčio beieškant: lietuviškos karinés minties raida ir būklè po nepriklausomybès atkūrimo (1990-2014), Vilnius: Lietuvos karo akademija, 2016, p. 14.
} 


\section{The Russian Concept of Contemporary Warfare after the Conflict with Georgia}

Discourse A involves the analysis of Russian authors' texts on contemporary and modern warfare that were selected from popular public sources that are clearly related to the Ministry of Defence of the Russian Federation: the magazines Военная Мысль, Вестник, Международные Процессы, ВоенноПромышленный Курьер, Солдат Удачи аnd Ориентир and the Красная Звезда portal. A total of 64 publications were found, but only 48 texts were analysed due to limited accessibility.

In the words of the President of the Russian Academy of Military Sciences, Major General Makhmut Gareyev, to identify the types of warfare that Russia should be able to operate in contemporary or modern war, one should first of all try to understand what kind of war or a scenario thereof (conceptually speaking) is most likely in the case of Russia, for this is the very thing that should become the indicator of effective decisions on the types of warfare and armed forces development ${ }^{52}$. This military discourse accentuates three types of war that are usually used by Russian military analysts in their texts on future military tendencies: local war (локальная война), armed conflict (вооруженный конфликт) and global war (крупномасштабная война). According to the Russians, global war (which is perceived as war between the superpowers - the US and China as often as not) is the least likely scenario. When it comes to global war, the most important thing is the mobilisation response of the state and its determination to use nuclear weapons. It is understood that large-scale military manoeuvres and altercations are gradually losing their significance and becoming unwelcome, which makes the prospect for this type of war rather unlikely or, speaking about continental Europe, even impossible. Nonetheless, Russia stresses that no one can predict future conflict and therefore it is unwilling to abandon the global war scenario completely; quite the opposite - it is trying to be prepared. The emphasis on preparedness

\footnotetext{
${ }_{52}$ In: М. Елисеева, Уроки На Все Времена 27/10/2017, http://old.redstar.ru/2010/10/27_10/1_06.html, 15/12/2017. The author of the article provides a summary of the Russian Army Major General M. Gareev's ideas voiced at the scientific practical conference 'Russia in Wars of the 19th-20th Century. Lessons Learned and Conclusions'.
} 
is particularly noticeable in statements from the military elite $e^{53}$.

The concept of a military (armed) conflict in Russia is connected to possible disturbances within the country, potentially from terrorist attacks. Doubts regarding the global 'war on terror' strategy that the Russians referred to as a myth, a weapon of western states that enables the West to operate on the territories of other countries for their own insidious purposes, are particularly pronounced. Notably, an escalation of this type of military conflict in the country could easily become a civil war aimed at causing instability in Russia. In this case, the Russians believe this could lead to the advent of a trinity of terrorism-separatism-illegal military groups, where the line between a military conflict and local war is very fragile due to an overarching civil war. It is said that with an armed conflict the critical thing is to have a well-trained special force to be able to execute counter-terrorist operations - neutralise guerrillas, diversions, acts of terror and provocations ${ }^{54}$.

With Discourse A, the main focus lies in the prospect of local war and the emphasis on preparedness to wage this type of war. It is not just Russia's Defence Minister Sergey Shoigu or Major General Garayev, President of the Russian Academy of Military Sciences, who argue that local wars will be the predominant type of warfare in the future and that the Russian armed forces need to be thoroughly prepared to wage this type of war first and foremost; this

\footnotetext{
${ }^{53}$ С. Шойгу, Мы Должны Быть Готовы Ответить на Любые Вызовы и Угрозы, Ориентир 1, 2014, p. 4-7; Военно-Промышленный Курьер, Герасимов: Российкая Армия Готова к Крупномасштабным Войнам, 26/01/2013, https://vpk-news.ru/news/14180, 15/12/2017; М. Гареев, Искусство Решительных Действий, 11/06/2013, https://vpk-news.ru/articles/16298, 15/12/2017; А. Лунёв, В. Пятков, Снизу Горь Кавказские, Сверху - Русский Десант, 09/07/2009, http://old.redstar.ru/2009/07/07_07/1_02. html, 15/12/2017; С. Исаков, Цена Инициативы, Солдат Удачи 11 (170), 2008, p. 4-9; В. Калюжный, Стратегия Развития Современной России: Направления и Ожидания, Ориентир 11, 2013, р. 7-11; С. Виктор, С. Анатолий, Г. Александр, Т. Александр, Большой Стране Нужна Большая Армия, 17/06/2013, https://vpk-news.ru/articles/16731, 19/12/2017; Г.А. Налетов, К Вопросу о Разработке Концепици Нетрадиционных Войн и Вооруженных Конбликтов (Новые Формы и Способы Ведения Вооруженной Борьбы), Вестник Академии Военных Наук 1 (38), 2012, p. 29-34.

${ }_{54}$ В. Л. Ченгаев, С. В. Баленко, Условия Возникновения Вооруженных Конфликтов в ХХІ Веке на Территории Российской Федерации и Возможный их Характер в Период Обострения ВоенноПолитической Обстановки, Военная Мысль 9, 2009, р. 3-7; А. В. Сержантов, А. П. Мартофляк, Анализ Особенностей Современных Военньх Конфликтов, Военная Мысль 5, 2011, р. 36; Красная Звезда, Войны Будущзего, 13/07/2011, http://old.redstar.ru/2011/07/13_07/5_02.html, 26/01/2018.
} 
is the opinion of Russian warfare experts as well ${ }^{55}$. The significance of the dominance of local war in Russian military thought is shaped by virtue of several insights in analysing the general context. First of all, assessment is made of potential real military threats and challenges to Russia in the foreseeable future, accentuating the existence of hotspots close to Russia's borders, and therefore the military should be able to stabilise potential local wars in the post-soviet space (with Georgia, Ukraine and Armenia identified as bearing the highest potential to become sources of this type of conflict). Second, reflection is given to the modern military experiences of the western states of the second half of the $20^{\text {th }}$ century and the $21^{\text {st }}$ century, which reflect the entrenchment of the tradition of local war in contemporary military conflicts. The third perception of the likelihood of local war is biased towards Russias own experiences in the 2008 war with Georgia, thus making inferences and looking for solutions that would be effective in contemporary local war.

Even though there are prospects for three types of war disseminated in Russian military discourse since the Georgian war, there is yet another position that basically doubts the potential of science to predict the character of modern warfare and which challenges the objectivity of the classification of war on the grounds of its inherent complexity and the breadth of the spectrum of its intrinsic characteristics. In doing so, the focus is placed on the conceptual element of military power, when intellectual efforts need to be made to identify the nature and understand the principal characteristics of a war that has broken out. It is not by accident that such efforts are focused on attempts to understand the main and predominant types of warfare that can be realised in a contemporary war, especially considering the effective and appropriate training, grouping, provisioning and deployment of the armed forces in military operations ${ }^{56}$.

\footnotetext{
${ }^{55}$ Калюжный, (supra note 53); Шойгу, (supra note 53); Военно-Промышленный Курьер, (supra note 53); М. А. Гареев, Характер Современных Военных и Невоенных Угроз Безопасности России и Организащия Обороны Страны, Вестник Академии Военных Наук 4 (45), 2013, p. 4-9; А. Медин, Ответ на вызовы времени, 18/03/2011, http://old.redstar.ru/2011/03/18_03/5_01.html, 20/12/2017; A. Гавриленко, Флот смотрит в будущее, 01/07/2009, http://old.redstar.ru/2009/07/01_07/1_10.html, 20/12/2017; В. И. Евдаков, С. Д. Мещеряков, Характерные Черты и Особенности Войн Начала ХХI Века, Вестник Академии Военных Наук 3 (24), 2008, p. 18-21; С. Г. Чекинов, С. А. Богданов, Злияние Непрямых Действий на Характер Современной Войны, Военная Мысль 6, 2011, p. 3-13; Лунёв, Пятков, (supra note 53); С. А. Буяновский, П. А. Дульнев, Взгляд на Развитие Форм и Способов Применения Общевойсковых Соединений в Условиях Изменившегося Характера Вооруженной Борьбы, Вестник Академии Военных Наук 3 (40), 2012, p. 165-169.

${ }^{56}$ А. Сушенцов, Типология Поведения в Международных Конфликтах, Международные Процессы 3 (24), 2010, http://www.intertrends.ru/twenty-four/007.htm, 20/12/2017; М. И. Орлов, Некоторые Проблемы Подготовки и Ведения Наступательных Операций в Современных Условиях, Военная Мысль 12, 2010, p. 23-28.
} 
The military terms that define the Russian perception of contemporary warfare and are most obviously dominant and significant in the Russian texts covered by the analysis are these: asymmetrical warfare (асимметричная война or асимметричный вооруженный конфликт), controlled chaos or colour revolutions (управляемый хаос or цветная революция), networkcentric warfare (сетецентрическая война) and new types of armed forces (новый облик Вооруженных сил).

In the Russian military discourse, asymmetrical warfare is perceived to be effective thanks to its universal nature. The universal character of asymmetry in a conflict is defined by three methods to employ this type of warfare: (a) asymmetry is achieved through available military-technological measures; (b) asymmetrical actions become the military strategy of the weaker party; (c) asymmetrical warfare is realised through non-military measures. In the first case, Russia places particular emphasis on military technological systems of systems, which are necessary to develop a military technological asymmetry (военная-технологическая асимметрия) in war on its own initiative, thus securing an advantage when the available options allow for an attack on the opponent's objects without any direct contact or even without landing on the opponent's continent ${ }^{57}$. There is an active ongoing debate among Russian experts regarding the effectiveness of asymmetrical warfare when asymmetry becomes the military strategy of the weaker party, for it is believed that this is the most plausible strategy of enemy acts against Russia in the event of a future local war. In this case, the predominant role is expected to be played by guerrilla fighting tactics that can be deployed by contemporary terrorist or illegal military groups and involve cautious, portioned, low-intensity skirmishes with the structurally stronger opponent to achieve political and strategic rather than military goals ${ }^{58}$. The discussions on asymmetrical warfare also touch on non-military measures (невоенные средства), which are directly associated with indirect (non-traditional) acts (непрямые (нетрадиционные) действия) in contemporary war. It is indirect acts that are perceived as the inevitable elements of contemporary war, considering the possibilities to act asymmetrically. In this case, asymmetrical warfare takes on a wider range of

\footnotetext{
57 Гареев, (supra note 53); Л. Н. Ильин, В. Г. Ковалев, А. С. Муратханов, Ориентиры для Создания Вооружения и Военной Техники Сухопутных Войск, Военная Мысль 4, 2011, p. 35-36.

${ }_{58}$ С. Г. Чекинов, С. А. Богданов, Асимметричные Действия по Обеспечению Военной Безопасности России, Военная Мысль 3, 2010, p. 16-17; Сержантов, Мартофляк, (supra note 54) p. 40; Е. А. Степанова, Асимметричный Конфликт как Силовая, Статусная, Идеологическая и Структурная Асимметрия, Военная Мысль 5, 2010, р. 48-53; Л. Дериглазова, Асимметричный Конфликт $в$ Современной Американской Политологии, Международные Процессы 2 (23), 2010, http://www. intertrends.ru/twenty-three/006.htm, 21/12/2017.
} 
actions, where indirect actions can be made without relying on military hi-tech, engaging covert methods and measures focused on the enemy's political, social and information aspects instead. It has to be noted that the US and NATO have been using such indirect actions in their military campaigns to a large extent, which makes them increasingly relevant and popular in contemporary conflict ${ }^{59}$.

Whilst analysing the concept of controlled chaos, Russian experts stress that the contemporary method of this form is the colour revolutions that both have their own potential as a tool of aggression and actually pose a threat to Russia as such. However, this method relates to non-violent measures aimed at initiating and maintaining chaos in the target country and using it to affect the country's social-political structures and change its governance. Controlled chaos focuses on the interior control of other states for the purposes of dominance in the information space and using it to cause a revolution, attempting to exercise psychological influence on and manipulating the civil masses of the state. Still, Russia tends to equate colour revolutions to a state of war and considers taking adequate military countermeasures (as a defence response). Russia accentuates the long-term operating strategy of controlled chaos, when the covert methods of the aggressor are maintained actively through exterior funding of target assets or infrastructures, and the revolution in its own right is but a stage of the active phase, one that requires fast action without revealing the aggressor's true interests or direct involvement ${ }^{60}$.

There is a particularly active debate going on in Russia with regard to the theoretical and practical opportunities to develop a state-of-the-art military technological potential in future to secure dominance in a military conflict by way of the concept of network-centric warfare, for there is a firm belief that this type of warfare will become a key feature of future conflicts and operations ${ }^{61}$. The uniquely Russia perception of this type of warfare is best summarised by the innovative principle of the realisation of military power as formulated by Viktor Tatarinov:

\footnotetext{
59 Чекинов, Богданов, (supra note 58) p. 19-21; Чекинов, Богданов, (supra note 55) p. 4.

60 В. И. Кузьмин, Н. А. Галуша, В. А. Рябошапко, Управляемый Хаос как Технология Организации. «Нового Мирового Порядка», Вестник Академии Военных Наук 2 (39), 2012, р. 94-99;

В. В. Татаринов, Элементы Сетецентрической Защзиты, Вестник Академии Военных Наук 1 (42), 2013, p. 91-92; Гареев, (supra note 53) p. 5-6.

${ }^{61}$ А. Фомичёв, Изучая войну будущего, 15/01/2011, http://old.redstar.ru/2011/01/15_01/1_04.html, 22/01/2018; Орлов, (supra note 56) р. 23-24; А. Е. Кондратьев, Общзая Характеристика Сетевых Архитектур, Применяемых при Реализации Перспективных Сетецентрических Концепиий Ведущих Зарубежных Стран, Военная Мысль 12, 2008, р. 63-64; И. Н. Воробьев, В.А. Киселев, Om Современной Тактики к Тактике Сетецентрических Действий, Военная Мысль 8, 2011, р. 20; А. А. Рахманов, Сетецентричекие Системы Уравления: Законамерные Тендениии, Проблемные, Вопросы и Пути их Решения, Военная Мысль 3, 2011, p. 41-42.
} 
'strict centralisation - network realisation' ${ }^{62}$. The most optimal form of that realisation is constructed through two integral platforms (платформоцентризм), of which one is focused on the command and control of military forces, signals, information and intelligence, and the other on the possibilities to execute military deep attacks and strikes, or precision strike weapons systems that allow for the development of a dominating manoeuvre (господствующий маневр) in war. Russian experts simulate the effectiveness of the network-centric platform by way of the implementation of internal synergy or automated synchronisation, believing however the opportunities to strike the enemy's assets from the depth of its territory to be the critical success factor in a future war. It has to be emphasised that this concept is gaining a rather futuristic vision in Russia, because the discussion is about using technology that does not yet exist and may take up to 40 or 50 years to arrive, all the while trying to predict the impact of artificial intelligence on the shrinking role the human factor will have in future wars. In the same context, space is being referred to a great deal, and so is the need to dominate it and use it to attack assets located in any part of the world. Hence, this concept is rather a reflection of Russian warfare experts' attempts to respond quickly to the approaching revolution in military affairs, which is instigated by advanced information and technological innovations ${ }^{63}$.

It is in the discussions of Russian warfare experts about the need to develop, have and use network-centric warfare platforms in future wars that the term new types of armed forces makes its appearance, only to take on a futuristic meaning rather than constitute an attempt to disseminate this term as a cornerstone concept in future military conflicts. This term can only be considered a military concept to a certain extent, for it is focused on military structural reforms dominated by the physical component (structure, weaponry and technology) of the armed forces. Conceptually speaking, this term connects to the ability to achieve a speedy military victory with minimal losses whilst being able to wage a contact-free war, eliminating the strategic assets of the enemy and paralysing its information and governance systems. Still, the usage of this

\footnotetext{
${ }^{62}$ Татаринов, (supra note 60) p. 94, (Rus. Жесткая централизация - сетевая реализация).

${ }^{63}$ А. Е. Кондратьев, Когда «Сетецентризм» Придет В Российскую Армию?, Вестник Академии Военных Наук 2 (39), 2012, р. 120-125; Б. Ф. Чельцоь, Проблемы Создания Сетецентрической Системь Управления Войсками, Силами и Средствами ВКО, Вестник Академии Военных Наук 4 (37), 2011, p. 56-60; В. Герасимов, Генеральный Штаб и Оборона Страны, 03/02/2014, https://vpknews.ru/articles/18998, 23/01/2018; А. Н. Захаров, А. Д. Хряпов, С. Н. Петруня, Вооруженная Борьба Эпохи Информации, Вестник Академии Военных Наук 2 (43), 2013, р. 70-74;

Б. И. Клзарьян, Операции, Боевые Действия, Сетецентричная Война, Военная Мысль 2, 2010, p. 25-37; А. Е. Кондратьев, Проблемные Вопросы Исследования Новых Сетецентрических Концепций Вооруженных Сил Ведущих Зарубежных Стран, Военная Мысль 11, 2009, p. 64-65; В. Н. Горбунов, С. А. Богданов, О Характере Вооруженной Борьбы в ХХІ Веке, Военная Мысль 3, 2009, р. 5-6.
} 
term rather reflects the reforms taking place within the structure of the Russian armed forces and weaponry as well as the idealistic expectations that are supposed to bridge the gap between the progress of military thought and the needs of military practice - the ability to wage sixth-generation warfare dominated by high-precision weapons and high technologies ${ }^{64}$.

To sum up, it can be said that the types of warfare that were disseminated in Russian military thought after the military conflict in Georgia have acquired different meanings. While the perception of network-centric warfare and new types of armed forces is focused on the future that has to do with would-be innovative-advanced technology, asymmetrical warfare and the controlled chaos strategy not only gain the meaning of a political-military threat to Russia but also become disseminated as the most effective and critical types of contemporary warfare that Russia needs to be able to employ if it wants to act proactively and not just reactively. The discourse reveals a systemic leaning of Russian experts towards analysing US military thought and US and NATO military operations such as Vietnam (1954), Iraq (1991), Yugoslavia (1999), Afghanistan (2001), Iraq (2003) and Libya (2011). Even through President of the Russian Academy of Military Sciences, Major General Gareyev, emphasises that Russia's experiences in Georgia have revealed a gap between Russian military thought and the available potential of its armed forces, the Russian army was incapable of waging a sixth-generation war in Georgia for pure lack of the necessary fighting systems and weaponry ${ }^{65}$. Still, one has to admit that there is a shortage of open discussion and analysis of soviet and latter-day Russia military experiences (the two wars in Chechnya and the armed Russia-Georgia conflict).

\section{The Russian Perception of Contemporary Warfare after the Outbreak of the Conflict in Ukraine}

Discourse B involves an analysis of Russian texts that were picked out of the same sources as Discourse A. However, with this discourse some new sour-

\footnotetext{
${ }^{64}$ И. Н. Воробьев, В. А. Киселев, Комментаррии к Статье 'Войны Настоящего и Будущего' Военная Мысль 5, 2011, р. 56; С. И. Макаренко, А. Н. Бережнов, Перспективы Использования Сетецентрических Технологий Управления Боевыми Действиями и Проблемы их Внедрения в Вооруженных Силах Российской Федерации, Вестник Академии Военных Наук 4 (37), 2011, р. 67; В. В. Бабич, О Подходах К Определению Форм Военных (Боевых) Действий, Вестник Академии Военных Наук 3 (44), 2013, p. 48; А. А. Корабельников, Что Такое Современная Тактика? К Чему Надо Готовить Войска? Чем Они Должны Быть Вооружень?, Вестник Академии Военных Наук 4 (45), 2013, p. 43.

${ }^{65}$ Гареев, (supra note 53 ).
} 
ces have appeared (such as the magazines Вестник Военного Образования and Проблемы Национальной Стратегии, and the web-based journal Независимая Газета), while the magazine Солдат Удачи was discontinued in 2010. Discourse B consists of a total of 117 publications; 38 texts were limited-access resulting in an analysis covering the contents of 79 texts.

\subsection{A Vision of Future War}

Russia's attempts to predict wars it may have to wage in the future reveal the same three types of war that were present in Discourse A, global (regional), civil (revolutionary) and local. In the case of global war, Russia is still strongly sticking to its guns that the probability of this type of war continues to be highly minimal, for war statistics reaching back to the mid- $20^{\text {th }}$ century show that none of over 400 military conflicts blew up to become a global war between coalitions or two major powers fighting between each other. Wars are emphasised to have transformed into medium- or low-intensity conflicts with major powers fighting among themselves by way of third parties, understanding that direct military confrontation is curbed by the availability of nuclear weapons ${ }^{66}$.

There is, however, the feeling of a stronger potential for a limited military conflict that could take place both on the interior territory of Russia and around its perimeter or in more remote zones of Russia's interests. The key difference in terms of the potential for a civil war in Russia is the new actor in the global context: the Islamic State of Iraq and the Levant, its destabilising threat to Russia perceived in two ways. First of all, it is argued that since 2015 the operations of this non-governmental terrorist group have spread far beyond the borders of Iraq and Syria, and that one of its potential targets now is Russia, and the Chechen Republic and the Republic of Dagestan in particular, where religious discord, extremism and ethnic disturbances could be escalated

\footnotetext{
${ }_{66}$ О. Половенко, Гибридная война: миф или реальность?, 02/02/2015, http://www.redstar.ru/index. php/news-menu/vesti/iz-moskvy/item/21475-gibridnaya-vojna-mif-ili-realnost, 13/03/2018; В. И. Ковалев, Г. Г. Малинецкий, Ю. А. Матвиенко, Концепция,Сетецентрической` Войны Для Армии России: ,Множитель Силь' Или Ментальная Ловушка?, Вестник Академии Военных Наук 1 (50), 2015, р. 70; Б. А. Александрович, Модель Адаптивного Применения Силь В “Цветных Революииях”, Проблемы Национальной Стратегии 6 (27), 2014, р. 113; Б. А. Александрович, Применение Гибридных Методов в Современных Конфликтах, Проблемы Национальной Стратегии 6 (39), 2016, р. 158; Х. И. Сайфетдинов, Информационное Противоборство В Военной Сфере, Военная Мысль 7, 2014, p. 38-42.
} 
among the local Orthodox and Muslim Russians ${ }^{67}$. Second, terrorism is perceived as an instrument of indirect war that is growing increasingly stronger. In this case, the West is seen as a particular threat with perceived attempts to manipulate the terrorism card, when the activities of irregular military-terrorist groups can be combined into joint operations thus forming systemic strife against another state to achieve national interests. It is even stated that the West is trying to consolidate the conflicts in Ukraine, the Middle East, the Caucasus and Central Asia in order to guide this terrorist front against Russia. It is the threat of exterior (planned and coordinated) terrorism that is driving a shift in the more prevalent interior concept of terrorist threats, where ethnoconfessional-extremist conflicts among the local populace can be sparked and a civil war inside the country instigated ${ }^{68}$.

Still, the most realistic type of war that Russia might become engaged in the future is local war albeit with certain adjustments in Russian military thought compared to the military thought of Discourse A. If previous predictions of local war have concerned three post-soviet states (Armenia, Georgia and Ukraine), in the resumed discussions Russia is beginning to give serious regard to the probability of this type of war in states that have never been considered before: Kirgizstan, Uzbekistan, Kazakhstan, Moldova and Belarus. All of which gives rise to new challenges for the Russian armed forces, which have to be capable of stabilising local war once it breaks out and preventing this type of war from distracting Russia from defending its interests in other hotspots or regions ${ }^{69}$.

\footnotetext{
${ }^{67}$ А. С. Куликов, Проблемы Обеспечения Внутренней Безопасности Страны В Современных Условиях, Вестник Академии Военных Наук 3 (56), 2016, р. 6; В. Хорешко, Кривое Зеркало Терроризма, Ориентир 9, 2015, р. 8-11; Р. И. Игоревич, Приоритетные Задачи Совершенствования Международного Сотрудничества В Противодействии Терроризму, Проблемы Национальной Стратегии 1 (28), 2015, р. 105-112.

${ }^{68}$ Г. И. Пещеров, Проблема Терроризма: Причины и Пути Решения, Вестник Академии Военных Наук 3 (56), 2016, p. 10; С. Константин, Партизаны На Довольствии, 10/04/2017, https://vpk-news.ru/ articles/36159, 13/03/2018; В. Хорешко, Кривое Зеркало Терроризма, Ориентир 8, 2015, p. 10-13; А. Бакланов, Сирийский Синдром, Ориентир 6, 2016, р. 8-11; В. Пушкин, Из Сирии Взорвать Евразию?, Ориентир 8, 2017, р. 9-13; Г. Л. Витальевич, Угроза Новой Волны Исламского Терроризма $в$ Юго-Восточной Азии, Проблемы Национальной Стратегии 4 (31), 2015, p. 162-163.

${ }^{69}$ К. В. Васильевич, Современные Кризисы И Конфликты: Особенности, Сценарии Развития и Предотвращение, Проблемы Национальной Стратегии 4 (25), 2014, p. 136; Х. О. Сергеевна, Цветные Технологиид и Риски для Государственности: Украинский Опьт, Проблемы Национальной Стратегии 6 (39), 2016, p. 125-135; Пушкин, (supra note 68) p. 12-13.
} 


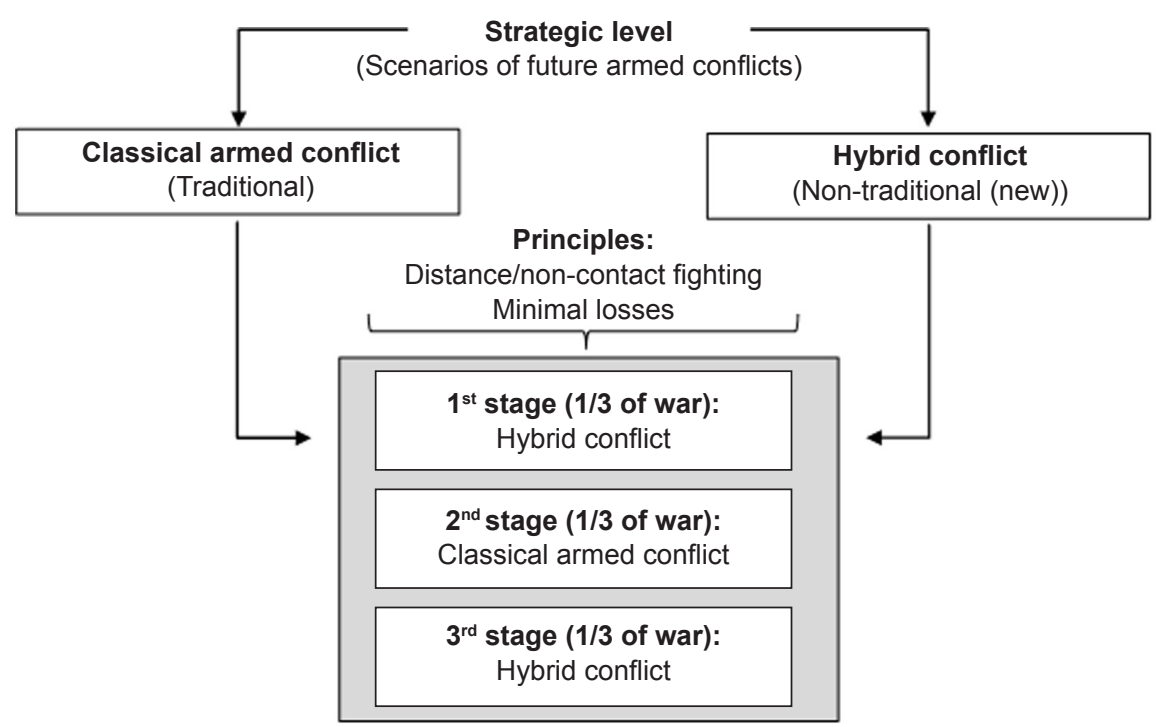

Figure 3. Russian concept of future war

(made by the author)

Attempts to predict the nature of future conflicts by Valery Gerasimov, Chief of the General Staff of the Russian Armed Forces, and warfare experts Valery Kiseliov and Tatyana Gratchevitch feature the concepts of the classical armed conflict (классический вооружённый конфликт) and hybrid conflict (гибридный конфликт) scenarios. Classical armed conflict is also classed as a traditional type of warfare, whereas hybrid conflict is considered to be a new trend in warfare, one that combines unconventional forms of aggression towards a state, which have become very popular in the West and in the US in particular. Notably, answers to the question of how these two types of conflict are interrelated and how they reinforce and support each other as well as what new challenges are posed by the combination of these two scenarios that are being sought are rather conceptual in nature. With the concepts of both of these conflicts, the critical point is the ability to act at a distance and without direct contact (дистанционная-бесконтактая) to minimise one's own casualties in the conflict. It is these abilities that should become the cornerstone characteristics of Russia's armed forces in contemporary warfare. What is new is that a hybrid conflict can take place in the absence of a classical conflict, yet a classical conflict is hardly imaginable these days without a hybrid conflict. It is predicted that future wars will consist of $2 / 3$ hybrid and $1 / 3$ classical conflict, with $1 / 3$ hybrid conflict used in the $1^{\text {st }}$ stage to minimise casualties in the 
succeeding classical stage and the wars eventually ending with a realisation of the remaining $1 / 3$ hybrid conflict to reinforce the achievements or subdue opposing military groups (Fig. 3). Looking into the future, traditional conflict is biased towards using high technology to design and develop precision weapon systems, while the unconventional conception leans towards causing a harmful (and covert, as often as no) effect with non-military (political, diplomatic, economic, financial, cyber, psychological, etc.) measures. According to the Russians, a contemporary case of the interrelation between these conflicts is the 2011 military campaign in Libya, where both military measures (such as a sea blockade, a no-fly zone, precision missiles, air attacks) and non-military measures (such as forming an opposition, arming irregular groups, cyber and information attacks) were deployed ${ }^{70}$.

Analysing the discourse of contemporary warfare in Russian texts written by military officers and warfare analysts after the beginning of the conflict in Ukraine, we can see that contemporary and future conflict is defined in Russian military thought by the following key types of warfare: first of all, the concept of classical armed conflict is shaped by network-centric warfare, information warfare (информационная воевания(борьба)) and radio-electronic warfare (радиоэлектронная борьба); in the meantime, at the heart of hybrid conflict lie hybrid aggression (гибридная агрессия), controlled chaos and colour revolution.

In the midst of these discussions, one can observe exhortations by President Vladimir Putin himself to think actively about the key and intensive changes in contemporary warfare that drive the armed forces to step up their thinking of adopting new weapons systems and brainstorm how they can be used effectively, all the while giving an increasing amount of consideration to the effectiveness of non-military measures in a military conflict ${ }^{71}$.

The types of warfare (network-centric warfare, colour revolution and controlled chaos) that dominate Discourse B were among the cornerstone types that defined the concept of contemporary warfare in Discourse A, but to reveal the causality

\footnotetext{
${ }^{70}$ В. В. Герасимов, Организация Обороны Российской Федерации в Условиях Применения Противником ,Традиционньхх и, Гибридньх“ Методов Ведения Войнь, Вестник Академии Военных Наук 2 (55), 2016, p. 19-20; Т. Грачева, Когда Объявлять Мобилизацию, 14/09/2015, https://vpk-news. ru/articles/27018, 14/03/2018; Т. Грачева, Армия На Подхвате, 03/08/2015, https://vpk-news.ru/articles/26404, 24/03/2018; Александрович, (supra note 66) p. 158-159; В. А. Киселев, К Каким Войнам Необходимо Готовить Вооруженные Силь России, Военная Мысль 3, 2017, р. 37-39.

${ }^{71}$ С. Шойгу, Дорогие Читатели!, Вестник Военного Образования 1 (1) 2016, р. 1; М. А. Гареев, В Интересах Обороноспособности Странь, Вестник Академии Военных Наук 1 (50), 2015, p. 4 -7 (The author of the article quotes points in President of the Russian Federation Vladimir Putin's speech when the president emphasises the importance of military science conceptual progress); Д. О. Рогозин, Формирование Нового Научнотехнического Задела - Одно из Важнейших Направлений в Противодействии Военньм и Невоенным Угрозам, Вестник Академии Военных Наук 2 (55), 2016, р. 4-6.
} 
of the dissemination and consumption of these types of warfare in the discourse and the significance of their perception, all of the six types of warfare that are predominant in Discourse B will be analysed in the following chapters.

\subsection{The Concept of Classical Armed Conflict}

In Russia's opinion, the key form of warfare in modern conventional conflict is network-centric warfare. Russian military experts and officers consider this form of warfare the main novelty and prospect in contemporary armed conflict, one that has elevated the potential of armed forces to the next level thanks to hi-tech and information and communications technology. In addition to the conceptual sources of network-centric warfare and the potential technological revolution in warfare that was discussed in Discourse A, this discourse is also concerned with a quest to understand the practical aspects of the realisation of this type of warfare through an analysis of recent military campaigns. The origin of network-centric warfare in Russian military thought is believed to be the 1991 war in Iraq, when US troops are estimated to have attacked some $8 \%$ of Iraqi strategic and military object using measures and methods of network-centric warfare. Notably, the popularity of this type of warfare has been on a continued increase due to its positive effect on the effectiveness of NATO and the US armed forces, when similar attacks were made against as many as 35\% of all high-value object in Yugoslavia in 1999, 50\% in Afghanis$\tan$ in 2001, and a massive 68\% in Iraq in $2003^{72}$. Discussions on the effectiveness of network-centric warfare highlight the synergy effect where not just the separate branches of the armed forces but also three hi-tech subsystems (information, sensory and weaponry) designed to gather, process, analyse intelligence, simulate scenarios and attacking object assets are combined into a single control and command system. The popularity of network-centric warfare was also a product of the transformation of conflicts as such into low-intensity confrontations that require a rational and rapid usage of military capabilities, for instance to execute long-distance military strikes deep inside enemy territory. Such opportunities enable adaptive military operations (адаптивные действия), where no pre-planned operation is necessary and targets can be attacked with the air force, navy or missiles immediately after they are detected. All of these network-centric warfare capabilities are seen in Russia as a future potential, which is already being tested little by little in the military conflict in Syria, using Kaliber cruise missiles launched off navy platforms located 1,500

\footnotetext{
${ }^{72}$ Киселев, (supra note 70) p. 38.
} 
kilometres from the target, and joint naval, air and land operations are being steered directly from Russia, which is more than 3,000 kilometres away ${ }^{73}$.

Even though network-centric warfare is attracting an increasing amount of attention in Russian military thought thanks to the potential it carries in future armed conflict, an equal amount of attention is being given to the threats that this type of warfare pose to Russia in their own right. Even though Russian experts do note that network-centric warfare has only been effective in confrontations between the West and technologically weaker countries, the concept of the threat of this type of warfare is being upheld at the same time, believing that the US is all the more approaching the potential to execute a global integrated-instant operation (глобальная интегрированная-мгновенная операция). This potential is predicted to become the blitzkrieg of the $21^{\text {st }}$ century, for the US would be able to attack any point on the globe from one to six hours after the decision is made. The key aspect of the operation is the development and use of supersonic missiles (сверхзвуковые ракеты) in both low- and high-intensity conflicts. Russia realises that it can hardly catch up with the US in this field, but there is no reason to fear either, because Russia has its tactical nuclear weapons that make up for the potential of an adequate strike. However, looking into the future, a vision is being modelled of the possibilities of emerging a technological triad (strategic nuclear missile force - missile defence system - highprecision weapon) that should ensure the country's security in case of military conflict with a technologically advanced state and would prevent the antagonist from gaining an initiative during the $1^{\text {st }}$ stage of the conflict ${ }^{74}$.

\footnotetext{
${ }_{73}$ В. Молчанов, Сетецентрические Войны и Будущее Поле Боя, 22/09/2015, http://www.redstar.ru/ index.php/news-menu/vesti/item/25847-setetsentricheskie-vojny-i-budushchee-pole-boya, 17/03/2018; А. Пинчук, Чтобы побеждать в гибридной войне, 22/01/2015, http://www.redstar.ru/index.php/zotov/ item/21219-chtoby-pobezhdat-v-gibridnoj-vojne, 17/03/2018; Ковалев, Малинецкий, Матвиенко, (supra note 74) p. 71-75; В. Барвиненко, Война на Опережение - Часть I, 29/06/2015, https://vpk-news. ru/articles/25872, 17/03/2018; А. Храмчихин, Армия Народа, 07/12/2015, https://vpk-news.ru/articles/28380, 17/03/2018; В. И. Литвиненко, И. П. Русанов, Основные Тенденции Огневого Поражения в Современных Операциях (Боевых Действиях), Военная Мысль 10, 2014, p. 19-26;

А. Е. Александров, О Перспективах Реализации Сетецентрических Концепций, Военная Мысль 5 , 2014, p. 18-25.

${ }^{74}$ В. Герасимов, По Опыту Сирии, 07/03/2016, https://vpk-news.ru/articles/29579, 17/03/2018; В. Яценко, От Народной До Гибридной, 10/08/2015, https://vpk-news.ru/articles/26515, 17/03/2018; В. Микрюков, Нездоровый Сетеиентризм, 27/02/2017, https://vpk-news.ru/articles/35371, 17/03/2018; С. Г. Чекинов, С. А. Богданов, Прогнозирование Характера и Содержания Войн Будущего: Проблемы и Суждения, Военная Мысль 10, 2015, p. 41-49; И. Д. Сергун, Взгляды Руководства Ведущих Иностранных Государств и Нато на Применение Вооруженных Сил в Современных Военных Конфликтах, Вестник Академии Военных Наук 2 (51), 2015, р. 37-38; В. И. Ковалев, Г. Г. Малинецкий, Ю. А. Матвиенко, Концепиия ,Сетецентрической“ Войны для Армии России: ,Множитель Силь' или Ментальная Ловушка? (Часть 2), Вестник Академии Военных Наук 2 (51), 2015, p. 94-99; В. К. Новиков, С. В. Голубчиков, А. В. Васильев, Концептуальный Взгляд на Проблему Устойчивости и Безопасности Мира, Вестник Академии Военных Наук 3 (56), 2016, р. 16; Киселев, (supra note 70) p. 43.
} 
The second form of warfare disseminated in the Russian concept of an armed conflict all the more strongly is information warfare, which can be accomplished by the armed forces through the use of measures of a cybernetic and psychological effect. Speaking of the psychological effect, the Russians emphasise that the human being is the weakest link in the modern military system and so an active information-psychological campaign should target not only the consciousness of ordinary troops but also the officers and even the military elite of the enemy, trying to cause panic among the soldiers, making the officers betray each other and initiating situations of vagueness and loss at the strategic-military level. Speaking about the technical potential for information warfare, the increasingly militarised cyber-space (for instance a NATO Cooperative Cyber Defence Centre of Excellence was launched in Estonia in 2009) merits a special mention. The cybernetic effect is emphasised to be rather biased towards the state government, public sector and banking systems or other non-military institutions of the enemy, trying to disrupt or paralyse any communications between the opponent's military and non-military element, diverting the attention of the latter away from potentially lending support to the armed forces. Even though the active ongoing discussion in Russia suggests that fighting over an information superiority in a traditional conflict is becoming increasingly fierce and its achievements cannot be denied, Russia still believes that the key point in modern conflict is weaponry and the potential it offers. That is why this type of warfare is rather seen as playing a supporting role in boosting the effectiveness of the armed forces and avoiding major casualties ${ }^{75}$.

The third predominant form of contemporary warfare in Russian military thought is radio-electronic warfare, accentuating scientific and technological progress affecting a vast usage of modern information and radio-electronic tools in the military sector. All of this allows progressive states to develop intelligence, communications, command and weapons systems of a very high level of effectiveness, which can then be used to achieve both military and political goals in a contemporary military conflict with great ease. These reasons make the enemy's military command and control network, its functioning and security ensuring the effectiveness of the armed forces in armed conflict, beco-

\footnotetext{
${ }^{75}$ В. Герасимов, Мир на Гранях Войны, 13/03/2017, https://vpk-news.ru/articles/35591, 17/03/2018; И. А. Шеремет, Противодействие Инбормационным и Кибернетическим Угрозам, Вестник Академии Военных Наук 2 (55), 2016, p. 29-32; Микрюков, (supra note 74); Л. А. Евгеньевич, Использование Манипуляиионных Технологий в Процессе Украинского Государственного Переворота и Информационной Войны Против России, Проблемы Национальной Стратегии 3 (24), 2014, р. 139140; С. В. Гончаров, Н. Ф. Артамонов, Достижение Информационно-Психологического Превосходства в Современных Боевых Действиях, Военная Мысль 6, 2014, р. 61-69; К. А. Троценко, Информационное Противоборство в Оперативно-Тактическом Звене Управления, Военная Мысль 8, 2016, р. 21-24; Сайфетдинов, (supra note 66) p. 38-39; Александрович, (supra note 66) p. 160-164.
} 
mes the new military target. At the same time, the idea to attack the enemy's civil telecommunications assets deep within the territory is still there as well. The US was the first to demonstrate experiences of this kind in its attacks against key info-communications object in Yugoslavia (1999) and Iraq (2003) in order to paralyse the national telecommunications systems. Yet using these warfare measures in air force operations did not become a critical object of discussion of radioelectronic warfare; quite the contrary, a very active quest for rational ways and measures to integrate units of radio-electronic warfare into land force structures and military manoeuvres began in a bid to secure an upper hand in the sphere of information and usage of weapons, where the enemy's information, force and weapons control systems are neutralised or disorganised before any tactical land force actions can take place. These kinds of objectives can be achieved by radioelectronic taskforces capable of carrying out coordinated actions or combined military operations together with the land forces. At the same time, consideration is given to the future, in which actions are expected to be innovative, active and constructive in order to develop the capability of a radioelectronic-fire strike (радиоэлектронно-огневой удар) against the enemy's assets consisting of the possibility of an integrated attack of radio-electronic forces, missile forces, artillery, troops and tactical aviation. This new capability of combat units would lead to the complete superiority of the control of the Russian armed forces and the deployment of smart weaponry in future armed conflict and would become a key measure in contemporary military conflict $^{76}$.

\footnotetext{
${ }^{76}$ П. А. Дульнев, В. И. Орлянский, Основные Изменения в Характере Вооруженной Борьбы Первой Трети ХХІ Века, Вестник Академии Военных Наук 1 (50), 2015, p. 44-48; В. А. Дворников, И. И. Королев, В. Н. Павлов, О Тактике Войск Радиоэлектронной Борьбы, Военная Мысль 3, 2015, p. 9-15; А. С. Коробейников, Д. В. Холуенко, С. И. Пасичник, Эфбективность Группировки Войск Радиоэлектронной Борьбы в Ходе Комплексного Поражения Информационно-Управляющей Системы Противника, Военная Мысль 8, 2015, р. 24-29; Ю. Е. Донсков, О. Г. Никитин, П. Н. Беседин, Роль Интеллектуальных Систем Поддержки Принятия Решений При Управлении Радиэлектронной Борьбой в Общевойсковых Тактических Формированиях, Военная Мысль 10 , 2015, р. 33-40; В. И. Владимиров, В. И. Стучинский, Обоснование Боевого Применения Авиационных Носителей Средств Радиоэлектронной Борьбы в Оперативной Глубине для Завоевания Информационного Превосходства, Военная Мысль 5, 2016, р. 15-21; Ю. Е. Донсков, Ю. Н. Ярыгин, Д. М. Бывших, Координация Направлений Развития Сил и Средств Радиоэлектронной Борьбы с Направлениями Развития Сухопутных Войск, Военная Мысль 1, 2017, p. 16-21; А. Л. Морареску, Базовые Структурные Элементь Основ Оперативного Искусства Войск Радиоэлектронной Борьбы в Операциях Объединений Сухопутных Войск, Военная Мысль 5, 2017, p. 45-49;

В. А. Орлов, Ю. Н. Ярыгин, Д. М. Бывших, Планирование Стратегий Развития Системь Вооружения Радиоэлектронной Борьбы, Военная Мысль 5, 2017, р. 14-22; О. Г. Никитин, Направления Повышения Эффективности Организации Боевого Применения Войск Радиоэлектронной Борьбы в Операциях Объединений Сухопутных Войск, Военная Мысль 5, 2017, p. 23-29; В. А. Орлов, Ю. Н. Ярыгин, Д. М. Бывших, Оиенка Состояния Сил и Средств Войск Радиоэлектронной Борьбы в Целях Выєора Рациональной Стратегии их Развития, Военная Мысль 10, 2017, р. 28-37; Д. В. Холуенко, В. А. Анохин, А. С. Коробейников, А. А. Лахин, Радиоэлектронный и Радиоэлектронно-Огневой Удары - Основные Формы Применения Частей и Подразделений Радиоэлектронной Борьбы, Военная Мысль 11, 2017, p. 21-27.
} 
All these types of warfare and the practical recommendations to the Russian armed forces formulated on their basis lead to the assumption that contemporary armed conflict in future will continue to transform into a hitech war (высокотехнологичная война) with intensive planning for and execution of high-precision military, electromagnetic and information strikes against the enemy's key object (Fig. 4). And the entire transformation of armed conflict is described best by an observation by Kiseliov, a Russian expert on warfare, that in contemporary conflict "technology shapes tactics" 77 . With this technology, in addition to fighting in the conventional land, sea and air space, one also needs to consider the ability to wage war in new (intergalactic and information-cybernetic) spaces, where it is the various modifications of highprecision missiles rather than soldiers that are likely to be the heroes.

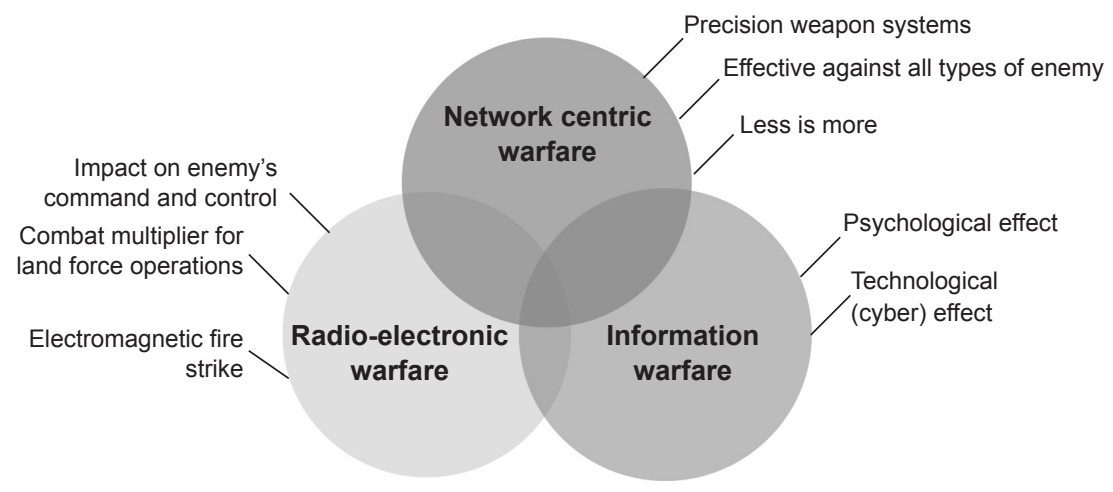

Figure 4. Classical armed conflict as a reflection of a high-tech war in Russian military thought

(made by the author)

\subsection{The Concept of Hybrid Conflict}

The term 'hybrid conflict' is not just a new thing in Russia's military vocabulary; it is also a complicated puzzle, one that requires answering the question as to whether it is a new military phenomenon or a rather specific, possibly even phantom term. To address this issue, the Russian armed forces employ methods that are intellectual (round-table discussions, science conferences ${ }^{78}$ ) and practi-

\footnotetext{
${ }_{77}$ Киселев, (supra note 70) p. 45, ('Техника определяет тактику' - rus.).

${ }^{78}$ Половенко, (supra note 66); Пинчук, (supra note 73); Н. И. Александрович, О Сущзости Гибридной Войны в Контексте Современной Военно-Политической Ситуации, Проблемы Национальной Стратегии 3 (36), 2016, p. 88; Красная Звезда, Изучают Гибридные Войны, 10/02/2015, http://www. redstar.ru/index.php/syria/item/21686-izuchayut-gibridnye-vojny, 26/03/2018.
} 
cal (military courses, scenario simulations, field exercises ${ }^{79}$ ). The discussions rely on the recent conflicts of the $20^{\text {th }}$ and $21^{\text {st }}$ century, which (both officially and unofficially, according to the Russians) involved or involve the US, because this country is believed to exercise the highest degree of professionalism in applying the hybrid conflict format. The latest examples of this format are the conflicts in South Africa, the Middle East and Ukraine, in which the western strategy of hybrid conflict was brought to life. The key point of this conflict is the goal of destabilising the country to avoid any major military casualties should armed forces intervention on a bigger scale be required, and to replace the government without any larger military manoeuvres. Again, the inevitably obvious thing is how active the Russian experts are in trying to prove that hybrid conflict is a western form of warfare, which western countries apply even against Russia as such; here, the most appropriate observation is by Russian warfare expert Alexander Hramchikhin on mutual propaganda: "The West (Russia) is waging a hybrid war against Russia (the West)"

Russia's intellectual reflection of hybrid conflict focuses on non-military, non-direct and covert reasons, goals and methods to break the government system of an opposing state. For all practical purposes, they are talking about a very wide range of measures including economic, political, energy, financial, information, cybernetic and other measures as well as combinations thereof. At a glance, this creates an impression that when it comes to these universal methods of effect, the concept of hybrid conflict becomes a kind of umbrella covering the multimodality of actions in an unconventional conf$\operatorname{lict}^{81}$. However, rather than attempts to define the concept of hybrid conflict or the ambitions to draw a list of all the possible methods that it covers, the key point in the discourse in question is to consider the goals of Russian experts to reveal the consistency of the strategy of hybrid conflict (as that of a prolonged and targeted action by a state). This strategy puts into a solid causal and logical

\footnotetext{
${ }^{79}$ А. Александров, Ни Мира, Ни Войны, 02/07/2017, http://www.redstar.ru/index.php/kozak/ item/33672-ni-mira-ni-vojny, 24/03/2018; Пинчук, Заслон Гибридным Операциям, 01/12/2015, http://www.redstar.ru/index.php/syria/item/26823-zaslon-gibridnymoperatsiyam?tmpl=component\&print=1, 24/03/2018; К. Сивков, Для Начала Переворот, 11/09/2017, https://vpk-news.ru/articles/38867, 24/03/2018.

${ }^{80}$ A. Храмчихин, Высокоточная Стрельба Вхолостую, 23/11/2015, https://vpk-news.ru/articles/28152, 24/03/2018, ('Запад (Россия) ведет против России (Запада) гибридную войну').

${ }^{81}$ А. Александров, В Прищеле Гибридной Войны, 30/10/2016, http://www.redstar.ru/index.php/component/k2/item/31027-v-pritsele-gibridnoj-vojny, 26/03/2018; Ю. Е. Кулешов, Б. Б. Жутдиев, Д. А. Федоров, Обзор и Анализ Содержания Психологических Операций ВС США в Вооруженных Конфликтах Современности, Вестник Академии Военных Наук 3 (48), 2014, p. 64-73; Герасимов, (supra note 74); Т. Грачева, Шаги Оккупанта, 27/07/2015, https://vpk-news.ru/articles/26297, 26/03/2018.
} 
chain the terms that are widely used in Russian texts to describe the contemporary form of warfare in reliance to non-traditional measures rather than military power. Thus, hybrid conflict in Russian thinking is divided into four phases of attack against a vast sector of a state's activities: (1) hybrid aggression, (2) controlled chaos, (3) colour revolution and (4) hybrid warfare (Fig. 5).

Hybrid aggression (long-term, active information campaign, developing opposition/5th column)

Controlled chaos (terrorism, demonstrations,

ethno-religious conflicts, information operations, use of force)

Colour revolution (change of state leader and government)

Hybrid warfare (fighting with non-military formations (bandits, $\subset$ insurgents, guerillas, terrorists), special operations (optional phase)

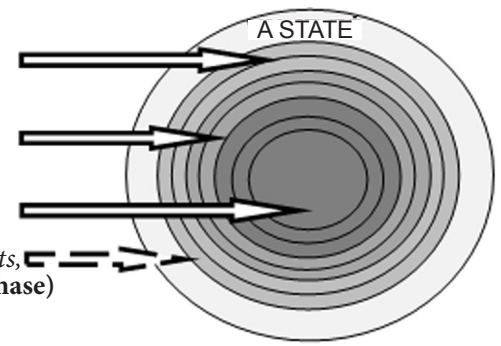

Figure 5. Russian concept of hybrid conflict

(made by the author)

Hybrid aggression is understood as a preparatory phase to spark an effective controlled chaos. This phase is described as highly specific and rather assumed, for it does not have a clear beginning, an action front or an end, it does not need to be officially declared but can be executed; also there are no winners or losers. The cornerstone aspect here is the ability to carry out long-term aggression against the state in which the government bodies are to be weakened, undermining its political, military, economic and psychological status. This long-term character is illustrated by the hybrid aggression of the West against Russia that Russian experts accentuate in their discussions; they argue that this aggression has been consistently in progress since 1990 or earlier. The aggression uses exclusively non-military measures to establish and reinforce the country's opposition or a $5^{\text {th }}$ column - in the case of Russia, pro-western (proliberal) political, non-governmental organisations or a network of them ${ }^{82}$. The essential measure and mode of operation of the aggression is considered to be an information campaign targeting three spaces: affecting the mentality of the people of the state, creating a favourable atmosphere on the international arena and forging a sense of innocence in the consciousness of its own citizens. Alexander Vladimirov, a reserve general and Russian expert on warfare, provides an apt illustration to this strategic nature of hybrid aggression by transforming

\footnotetext{
${ }^{82}$ Александров, (supra note 81); А. Бартош, Цветные Революиии и Гибридные Войны Современности, Независимой Газеты, 22/01/2016, http://nvo.ng.ru/gpolit/2016-01-22/1_revolutions. html, 30/03/2018; Васильевич, (supra note 69), p. 136-139.
} 
the famous saying by the Roman historian Cornelius Nepos ( $1^{\text {st }}$ century B.C.), "If you want peace, prepare for war", into "If you want peace, go to war." ${ }^{83}$ Even though hybrid aggression has an extremely broad range of measures, achieving the desired effect requires that this range be focused on the state's identified weak spots. And of all the possible weaknesses, the biggest is considered to be the conviction of the state as such that there is no exterior coordinated hybrid aggression coming its way from anywhere. Still, this phase does not consider using direct military measures, giving thought as to how the whole of the nonmilitary measures can be employed to minimise the use of military power or casualties in trying to achieve political objectives in the next phases instead ${ }^{84}$.

Controlled chaos is a hands-on phase of hybrid conflict within the target country, which involves the effective exploitation of measures that have been moulded and strengthened inside the country, seeking both to destabilise the status of the state and to weaken and break the government and political system of the state even more. The key aspect here is action premeditated by an external actor, which is usually limited to a period of four to six weeks, when efforts are made to create conditions for a colour revolution. In a controlled chaos setting, the element of military power becomes vital and inevitable, with the opposition and other groups being armed and trained, demonstrations and skirmishes initiated, use of force against protesters promoted and special forces infiltrated, terrorist attacks or diversions organised. Nonetheless, this phase is still dominated by non-military measures, the most prominent being an active information campaign that involves spreading ideological viruses' (идеологические вирусы) targeting the consciousness or mentality of the nation as well as other weak spots. Special emphasis is placed on cybernetic attacks that should help secure a dominant position in the information-communication space and cause confusion inside the country to launch attacks against healthcare establishments, banking systems and other public sector institutions. The Russian discussions accentuate that the architect of and expert in controlled chaos is the US that, back in 1980, changed the wording of the term controlled instability to controlled chaos and disseminates this concept as a technology of political activities ${ }^{85}$. According to some predictions,

\footnotetext{
${ }^{83}$ А. Владимиров, В Плену Болонской Системы, 27/02/2017, https://vpk-news.ru/articles/35356, 30/03/2018.

${ }^{84}$ Герасимов, (supra note 74); Герасимов (supra note 75); Бартош (supra note 82);

А. А. Корабельников, Дистанционный Разгром Противника в Контртеррористической Операчии: Дискурс Продолжается, Вестник Академии Военных Наук 3 (48), 2014, p. 26-29; А. Бартош, Адаптивные Стратегии Информационной Войны, Вестник Академии Военных Наук 2 (55), 2016, p. 85-93.

${ }^{85}$ В. Калюжный, Украина: Трудный Выбор, Ориентир 9, 2014, p. 4-8.
} 
controlled chaos may be launched in Russia, which makes it necessary to be able not only to give it the appropriate response (using the armed forces and ensuring information security) but to know one's own country's weaknesses and realise the conceptual premises for revolutions as well. It is stressed that this phase has the biggest potential in Russia's largest cities, when coordinated exterior support and chaos could engage the Russian 'patriotic-minded opposition, statistical alcohol and drug users, hooligans or bandits armed with illegal weapons, and so on. One of the best moments to trigger controlled chaos are a country's approaching political elections, so such critical moments must be watched very closely. Controlled chaos involves a mixture of military and non-military measures and methods geared towards affecting the mentality of the people and destabilising the country's economy, political and social environment and causing chaos within its governing bodies ${ }^{86}$.

In the Russian mentality, the cornerstone phase of hybrid conflict is a colour revolution, which has the sole aim of executing a takeover; therefore, the state needs to be able to stabilise this chaos and prevent a potential coup. The Russian discourse constructs a map of colour revolutions starting with the first colour revolution that took place in Yugoslavia in 1999 and then on to developments in North Africa, the Middle East and the post-soviet space (including the recent events in Ukraine) and making generalisations on that basis. Notably, these revolutions would often end in the establishment of a prowestern and anti-Russian authority in the country; this, according to President Putin, makes it an increasingly relevant problem to Russia as such revolutions demonstrate 'new rules or a game with no rules' in the world ${ }^{87}$. Time-wise, it is a short-lived phase that lasts four weeks or less, during which time a focused strike against the chosen government structure of the state is made. For all practical purposes, a colour revolution targets political leaders with attempts to attach one of two possible negative labels on them. The first is a bloody dictator, which the leader earns thanks to their decision to use military force

\footnotetext{
${ }^{86}$ Э. Шульц, Управление Социальным Протестом Как Технология и Содержание 'Арабской Весны', Международные Процессы 1 (13) 2015, p. 89-96, http://www.intertrends.ru/fortieth/Shults. pdf, 30/03/2018; Сивков, (supra note 79); А. Бартош, Навязчивая Богоизбранность, 31/10/2017, https://vpk-news.ru/articles/39633, 30/03/2018; В. Белозеров, Д. Копылова, Сми: Информационное Противоборство, Ориентир 5, 2014, p. 9-12; В. Белозеров, Цветные Революиии и Управляемый Хаос, Ориентир 10, 2015, p. 9-12; Александрович, (supra note 78), p. 86-91; А. Н. Бельский, О. В. Клименко, Политические Технологии Цветньх Революицй: Пути и Средства Противодействия, Военная Мысль 9, 2014, p. 3; Бартош, (supra note 82); С. Г. Чекинов, С. А. Богданов, Военная Стратегия: Взгляд в Будущее, Военная Мысль 11, 2016, р. 3-4. ${ }^{87}$ President of the Russian Federation Vladimir Putin's speech at annual discussion club 'Valdai' (2014 October 24): (Мировой Порядок: Новые Правила или Игра Без Правил? - rus.), In: Белозеров, (supra note 86$)$ p. 4.
} 
to quench demonstrations. The second is that of a 'corrupt leader' and is applied if the leader of the state does not choose to resort to military structures to halt protests. Both cases produce the same end result: the political regime is dismantled and the political leaders are replaced. Even though the revolution takes place inside the country, a third (concerned exterior) party may affect the leaders' actions in responding to the chaos, with threats to introduce armed forces or begin some other kind of intervention under cover of a humanitarian shield. Still, a revolution is considered to be most effective when a political victory is achieved with the third party acting indirectly and without any contact ${ }^{88}$.

To enforce the coup, exercise of military power may be required; this is when the colour revolution transforms into a civil war or continuous armed skirmishes inside the state. In this case we have hybrid warfare (гибридная воевания), its specific nature defined by unconventional and irregular military groups and their direct military actions. In essence, it is about regular forces fighting informal military formations, moving away from a revolution towards occupation through the perspective of humanitarian intervention or brotherly assistance. It is a continued anarchy in the state that is believed to offer the most favourable media to launch military actions by a third party, rendering an interior conflict international. Speaking of the conflicts in Syria, Libya, Iraq and eastern Ukraine, Russian experts can see the growing novelty of hybrid warfare, with irregular military groups actively using conventional military measures or even trying to fight by conventional methods. Such attempts become interlaced with the irregular military groups' known abilities to fight using guerrilla, diversion, terrorist and other unconventional combat tactics. In this phase, thought is given to hybrid warfare operations that the regular armed forces should be able to execute, for they are becoming a new way to act and fight and quite possibly even an alternative to conventional military operations that only require special forces or hi-tech weaponry. Still, this phase is not a prerequisite for a hybrid conflict, because an interior conflict within a state could be very hard to end with even adaptive military actions, which rather makes the introduction of armed forces as plan $\mathrm{B}^{89}$.

In summary, we can say that hybrid conflict is defined in Discourse $B$

\footnotetext{
${ }^{88}$ Бартош, (supra note 84) p. 88-92; А. Бартош, Трофейные Смыслыь, 30/01/2017, https://vpk-news.ru/ articles/34981, 30/03/2018; Васильевич, (supra note 69) p. 140-142; Александрович, (supra note 66) p. 115-116; Сергеевна, (supra note 69) p. 125-127.

${ }^{89}$ Грачева, (supra note 70); Храмчихин, (supra note 80); А. Зайцев, Партизанскими Методами, 01/09/2014, https://vpk-news.ru/articles/21649, 30/03/2018; В. А. Киселев, И. Н. Воробьев, Гибридные Операции Как Новый Вид Военного Противоборства, Военная Мысль 5, 2015, р. 41-42; Ю. А. Попков, Особенности Тактической Разведки в Гибридной Войне, Военная Мысль 8, 2017, p. 41-45.
} 
as a triad of hybrid aggression / controlled chaos / colour revolution with predominant non-military measures and methods, with the element of military power capable of activation through conventional and adaptive hybrid operations alike whenever necessary, expanding this triad further. Nevertheless, the Russian intellectual reflection of hybrid conflict in contemporary warfare is not grounded on Russia's own military experiences (with the one exception of Syria) but rather relies on the conceptual assumptions and military campaign practices of the West, drawing inferences and producing future insights on that basis. Unfortunately, Russia's own actions in the Crimea are not subject to public discussion or analysis, and the conflict in eastern Ukraine is rather presented as a realisation of a hybrid conflict instigated by the West (or the US in particular). For the purposes of these discussions, the Russian idea of hybrid conflict is rather perceived by virtue of the significance of its threat to the state of Russia or non-western regimes, with no open efforts to simulate Russia's potential to implement this kind of conflict scenario to attain political or military objectives outside its national borders.

\section{Conclusions}

After the conflict in Ukraine that started in 2014, the form of asymmetrical warfare which had firmly dominated Russian military thought since the 2008 Russia-Georgia war is now being replaced by the prospect of network-centric warfare, which is becoming the underlying subject in Russian discussions on contemporary warfare. Hence, the new Russian intellectual reflection ceases to analyse the specific nature of asymmetrical warfare and starts to look for conceptual solutions and simulate practical insights into how network-centric warfare could be realised that would enable the execution of adaptive military operations. Attention to network-centric warfare in the Russian mentality is a symbol of actively thinking about developing an advanced army that does not just have state-of-the-art military systems but is also able to use them in order to be proactive and operate with a high degree of intensity in a contemporary and modern hi-tech war. Notably, in doing so Russia is setting for itself ultimate military goals that focus on a timely internalisation of new technology in the fields of military systems. Hybrid is becoming a new and popular term in Russia's military vocabulary after the outbreak of the Ukrainian conflict. It is the non-military measures, previously the province of asymmetrical warfare, that are now being absorbed by the concept of hybrid aggression, while unconventional actions and operations against irregular armed forces are defined 
using the term hybrid warfare. After the conflict in the Ukraine, just as before it started, there is a great deal of attention in the Russian discourse of contemporary warfare given to non-military measures and their combination with military tactics, operationalising the controlled chaos and colour revolution types of action, which represent threats to Russia instead of gaining the meaning of an effective potential in armed forces operations.

Importantly, Russian military thought actively follows and analyses the military thought and experiences of the West, the US in particular, not only analysing the practical forms of warfare and their efficiency indicators and measures allowing them to be implemented in the most recent military campaigns, but also scrutinising the genesis of new warfare concepts and military terms in the western intellectual space. Both discourses consider the key conflicts in which Russian experts are trying to find objective conclusions regarding the predominant types of warfare to be those that took place in Iraq (1991), Yugoslavia (1999), Afghanistan (2001), Iraq (2003), Libya (2011), the Arab Spring domino effect in North Africa and the Middle East, and the revolutions in the post-soviet states. The Vietnam War (1955), which is considered to be the origin of asymmetrical warfare and had been the subject of broad analysis until 2014, has yielded its place to the military campaign in Syria (2011) with its hybrid and network-centric warfare.

It has to be admitted that the Ukrainian conflict, just like the RussiaGeorgia war before it, has failed to become the underlying note in Russia's discourse of contemporary warfare or the renewal of its military thought. Still, Russia is rather inclined to learn from western military campaigns and see them as a source of information on the key characteristics of contemporary warfare or the predominant types of warfare that have to be spotted, understood and internalised on time. At the same time, the Ukrainian conflict that started in 2014 is construed as a form of western warfare, a puzzle to Russia. All of this suggests that Russian military thought openly ignores the military experiences of the country just as it is potentially focused on propaganda actions in that regard. The important thing is that Russia's military practices in the Syrian military campaign are not being concealed. Quite the opposite; efforts are being made to highlight the country's practical actions and achievements aimed at anchoring the image of a modern army and showcasing military advancement to the home and international audiences.

Finally, even though the study did not pursue this objective, the research reveals disagreement (if only to an extent) with the stance of the western researchers referred to in the introduction to this article (such as McDermott, 
Galeotti, Thomas and Berzinš), who analysed texts that were more Russian in character, that in terms of modern military conflict Russia is rather thinking about the dominance and realisation of new-type warfare, new-generation warfare or non-linear warfare. Russia shows the will to be (conceptually) prepared and able to fight a sixth-generation war, its predominant features being contactless combat and high-precision weapon systems. This accentuates the strong future prospect of hi-tech warfare, in which network-centric warfare will play a key role. Nonetheless, the latest characteristic of contemporary conflict - its hybrid nature - is definitely not turning into a disorienting concept in the Russian military thought; on the contrary, Russian experts assign a strategic significance to this type of action and are looking for the most effective possibilities to use it to political-military ends instead of trying to assimilate it with other military terms (such as non-linear warfare).

June 2018 